\title{
A wider and more natural concept of the genus Gyromitra Fr.
}

\author{
HarriHarmaja \\ Department of Botany, University of Helsinki, Helsinki, Finland.
}

In the course of my studies on the genus Gyromitra I have found it unavoidable to expand the concept of that genus so as to include three genera usually considered separate, essentially because of differences in spore characters. Modern authors have treated Pseudorhizina Jačevskij (Helvellella Imai), Neogyromitra Imai (Maublancomyces Herter) and the old genus Discina (Fr.) Fr. as independent genera beside Gyromitra Fr. EGKBLAD (1968) too, maintains these genera except for Neogyromitra which he groups with Discina. On the other hand he writes that «smooth versus ornamented spores is a character of differentiating value on specific level only«. Benedix (1962) has even established for Neogyromitra and Discina a family of their own.

When delimiting the genus Helvella [L.] St.-Amans, Nannfeldt and Dissing (see Dissing, 1966) have emphasized the uniform anatomy of the excipulum together with the characters of the spores as the uniting characteristics of that genus. The form of the ascocarp is, on the contrary, most variable in the genus, from subsessile to ones with a very distinct lacunose stipe and a mitrate fertile cap. I have found their ideas to be valid and adaptable also in the delimitation of Gyromitra. According to my studies, in Gyromitra, Pseudorhizina, Neogyromitra and Discina the anatomy of the excipulum (as observed by EaKBLAD, 1968, too) and the paraphyses are much alike, and to a high degree the spores, too.
Pseudorhizina Jačevskij. This monotypic genus has been established for Helvella sphaerospora Peck because of the spherical spores of the latter. Subsequent authors (e.g. EckBlaD, op. c.) have not observed any other «significant« difference between it and the Gyromitra species. Though EkcBlad in his revision of the genera of operculate Discomycetes writes that «in no case is it obvious that a genus should be separated on spore form alone he still acknowledges the genus.

I have studied the lectotype of Gyromitra gabretae Kavina, which belongs to $P$. sphaerospora and found the excipulum to be composed of textura intricata as described by Eakblad (op.c.). The spores are small and completely spherical and a perispore cannot be distinguished. The spore wall is about $0,5 \mu \mathrm{m}$ thick as in species of Gyromitra. Many spores seem to be completely devoid of oil drops but probably most of them, however, contain one (some contain two or more) very small eccentric drop. The various species of Gyromitra s.lato have a characteristic number and size of oil drops in most of their spores but the drops can be lacking in a number of even mature spores. The fact that I have not observed any perispore in $P$. sphaerospora does not necessarily exclude the possibility of its existence. It may well be so thin and tightly appressed to the spore wall that other means than passive studying under the microscope are needed to detect it.

I have studied some specimens of Gyromitra californica (Phill.) Raitv. from Ciali- 
fornia and Idaho. This species is a true Gyromitra as verified by RAITvIIR (1965) and EckBlad (op.c.) and it seems to be nearlyrelated to $P$. sphaerospora both macroscopically and microscopically. The spores of $G$. californica are small, ellipsoid, without an observable perispore and most of them contain two very small drops, one at each end, but often not symmetrically located. Viewed from above, it is obvious that the spores of $P$. sphaerospora represent through those of $G$. californica one end of the variation of the Gyromitra spore and that the species belongs to that genus, where its correct name is Gyromitra sphaerospora (Peck) Saccardo.

Neogyromitra Imai. This genus has been established and used for stipitate species with «apiculate and sculpturate spores. At least two valid species have been recorded in the genus, $N$. gigas (Krombh.) Imai and $N$. caroliniana ([Bosc] Fr.) Imai.

According to the studies of LE GAL (1947) and my own, the appendages of the spores of $N$. gigas are but inflations of the perispore filled with some substance. The substance, periplasma, which is located between the spore wall and the perispore stains deep blue in Cotton Blue. Maas Geesteranus (1965) has found that the spores are principally similar in $N$. caroliniana. The deep-staining inflations of the perispore are, however, not restricted to these two stipitate species as it has been supposed when maintaining this genus. Probably RaitvirR (op.c.) was the first to find in $G$. infula and $G$. ambi- gua (s.n. G. infula v. apiculatispora Raitv.; see Harmaja 1969) the inflated perispore although he thought it was «the thickened epispore membrane«. He did not, however, consider this discovery very significant and he merely suggested that Gyromitra and Neogyromitra should be placed in the same tribus, but not united into one genus. Independently of him I have observed a perispore more or less inflated at the spore ends surround the spores of the same two species and of the type species of Gyromitra, G. esculenta, too. The periplasma stained always deep blue in Ciotton Blue as in $N$. gigas. In $G$. ambigua the inflations are rather wide and in some spores they are much like those of $N$. gigas. There is thus no principal difference between the spores of Gyromitra and Neogyromitra, to the contrary of what has been emphasized in the literature (see Fig. 1). There is, however, a reticulum, composed of an unknown substance, on the perispore of mature spores of Neogyromitra (and Discina; see Le Gal, op.c.). According to Eckblad (op.c.) the excipulum in $N$. («Discina«) gifas (also verified by me) and $N$. caroliniana is throughout composed of textura intricata which is the type of excipulum of Gyromitra s.str., too. $N$. gigas and $N$. caroliniana thus differ from the three Gyromitra species named above in that their mature perispore has a reticulum. This is an infrageneric difference only and the two species must be called Gyromitra gigas (Krombholz) Ciooke and Gyromitra caroliniana ([Bosc] Fries) Fries.

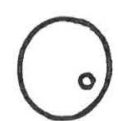

도.

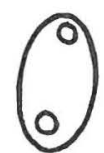

b

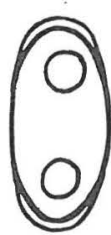

C

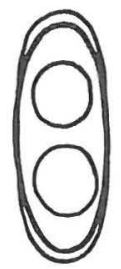

d

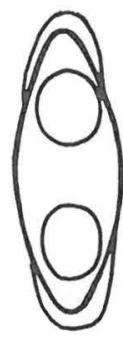

e

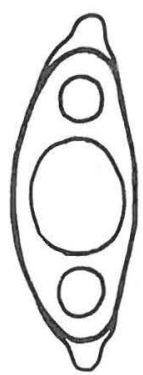

f

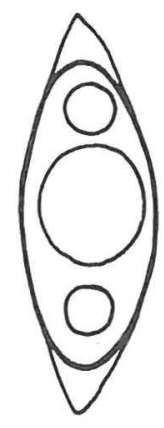

g

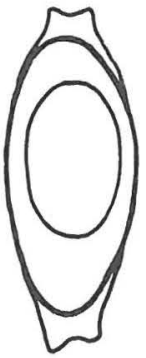

$\mathrm{h}$

Fig. 1. Spores of some species of Gyromitra, drawn x 1000 in heated Cotton Blue (the reticulum has not been drawn in $\mathrm{f}, \mathrm{g}$ and $\mathrm{h}$ ): a) G. sphaerospora (lectotype of $G$. gabretae), b) G. californica (Idaho, leg. A. W. Slipp), c) G. esculenta (Finland, Laitila, leg. K. Alho, I. Kause \& U. Laine), d) G. infula (Finland, Lohja, leg. H. Harmaja), e) G. ambigua (holotype), f) G. gigas (Finland, Järvenpää, leg. Y. Palmu), g) G. perlata (Finland, Lohja, leg. H. Harmaja), h) G. leucoxantha (type). 
Discina (Fries) Fries. There are at least two valid species in this genus, $D$. perlata (Fr.) Fr. and D. leucoxantha Bres. From the first-named I have studied several specimens collected by myself and others; from $D$. leucoxantha the type and another specimen collected by Bresadola. The excipulum of both species is composed of textura intricata as observed by EaKBLAD (op.c.) in the case of $D$. perlata. Their spores have a pronounced perispore which is reticulate at maturity and in each species it is inflated in a characteristic way at the spore apices because of the blue-staining periplasma. These characters of the spores of both species have earlier been studied and described thoroughly by Le GAL (op.c.). Accordingly, microscopically Discina species differ only very slightly from «Neogyromitra«. The fruit-bodies of Discina have a more or less distinct, mostly lacunose stipe (In D. perlata I have seen the stipe as long as $2 \mathrm{~cm}$ ). With age the hymenium usually gets folded and convex. Sometimes there is indeed not much separating Discina from «Neogyromitra«. The two genera have, however, nearly uniformly been treated as separate genera because of the distinct stipe and gyrose hymenium of Neogyromitra, the Discina species being indistinctly to shortly stipitate and having a discoid smooth hymenium at least when young. EckBLAD (op.c.) is the sole author to consider these differences unsatisfactory at the generic level and he united Neogyromitra to Discina. It is to be noted, however, that in his article as early as 1930, Corner considered Discina perlata as a very nearly-related derivative of Gyromitra gigas. This case resembles much the situation in the genus Helvella which includes both subsessile and distinctly stipitate species with almost uniform anatomy and spores. Accordingly, I agree with EckBLAD and consider Neogyromitra and Discina congeneric. In the preceding paragraph I have, however, united Neogyromitra with Gyromitra, from which it follows that the Discina species must be included in Gyromitra, too. Two new combinations become necessary: Gyromitra perlata (Fr.) Harmaja, n. comb. (basionym Peziza perlata Fries, Syst. Myc. II, p. 43, 1822) and Gyromitra leucoxantha (Bres.) Harmaja, n. comb. (basionym Discina leucoxantha Bresadola, Rev. Myc. 4, p. 212, 1882). Fortunately the name Gyromitra is older than the name Discina.
The emended genus Gyromitra Fr. thus contains distinctly to very shortly stipitate terricolous or lignicolous, vernal to autumnal species without dull colours (black, grey) and mostly growing in the neighbourhood of conifers. The excipulum is \pm uniform throughout and composed of interwoven, \pm filamentous hyphae (textura intricata). The spores are ellipsoid or oblong or \pm fusiform, rarely spherical, 1-, 2- or 3-guttulate, some to many of them may, however, have no or many guttules. The spores have a smooth wall ca. $0,5-0,8 \mu \mathrm{m}$ thick and are mostly (if not always) surrounded by a perispore. The perispore, when present, is more or less inflated (often in a characteristic manner) at the spore apices and the space between it and the spore wall is filled with periplasma deep blue in Cotton Blue. The periplasma is accordingly most prominent at the spore apices. In some species the mature spores have in addition a reticulum farthest off.

It is very probable that $G$. infula (and $G$. tasmanica ?; not studied by me) represents a rather primitive type in the genus. Assuming that the genus is monophyletic, G. sphaerospora would thus represent one end of the variation in Gyromitra, viz. towards simpler and smaller spores with smaller to no oil drops but towards a well developed fruit body (as also BeNEDIX, 1962, has suggested) whereas the Discina group would be at another end with the reverse evolution: the development of large thick-walled spores with a complex perispore and large and/or several oil drops, but the degeneration of the fruit body. A less plausible possibility is that the whole genus has evolved from Rhizina-like ancestors via the Discina group. I do not consider it probable that the Discina group is the most primitive one from which the stipitate Gyromitras would have evolved to one direction and Rhizina to another, opposite one.

The natural family Rhizinaceae Bon. sensu ECKBLAD (op.c.) contains beside the emended Gyromitra only one additional genus, Rhizina [Fr.] Fr. R. undulata (studied by me) has spores very similar to those of $G$. perlata, but it deserves a genus of its own because of the total lack of stipe, the «diffuse« yellow margin of the ascocarp, the rhizomorphs, and the deviating anatomy with setae and almost globose cells in the outer excipulum. 


\section{LITERATURE}

Benedix, E. H., 1962: Zur polyphyletischen Herkunft der Helvellaceen ss. lat. - Zeitschr. f. Pilzk. 27, 93-102.

Corner, E. J. H., 1930: Studies in the morphology of Discomycetes. IV. The evolution of the ascocarp. - Trans. Brit. Myc. Soc. 15, $121-134$.

Dissing, H., 1966: The genus Helvella in Europe with special emphasis on the species found in Norden. - Dansk Bot. Ark. 25, 1-172.

Eakblad, F.-E., 1968: The genera of the operculate Discomycetes. A re-evaluation of their taxonomy, phylogeny and nomenclature. - N. Mag. Bot. 15, 1-191.
Harmaja, H., 1969: A neglected species, Gyromitra ambigua (Karst.) Harmaja, n. comb. and G. infula s.str. in Fennoscandia. Karstenia 9, 13-19.

Le Gal, Marcelle, 1947: Recherches sur les ornementations sporales des Discomycètes operculés. - Ann. Sc. Nat., Bot., 11'e série, 8, $73-297$.

Maas Geesteranus, R. A., 19.65: Einiges über Neogyromitra caroliniana. - Proc. Koninkl. Ned. Akad. Wetensch., series C, 68, 128134.

RaitvirR, A., 1965: Taxonomical notes on the genus Gyromitra. - Eesti NSV Tead. Akad. Toim. 14, biol. seeria, 320-324. 